\title{
Analysis on the Challenges Faced by Australian Eastern Tuna and Billfish Fishery
}

\author{
Xinyue Zhao ${ }^{1, *}$ \\ ${ }^{1}$ The University of Tasmania, Tasmanian School of Business and Economics, Hobart 7019, Australia \\ *Corresponding author.Email: xinyue.zhao@utas.edu.au
}

\begin{abstract}
The Eastern Tuna and Billfish Fishery (ETBF) is an important part of the regional coastal economy and plays an important role in maintaining the stability of the ecological environment. This paper comprehensively discusses the challenges faced by ETBF from a wider range, including ocean current displacement caused by climate change, high labor power cost, uncertainty of global seafood trade and continuous increase of recreational fishery. It appears that both economic problems and climate change may bring more risks to ETBF, thus increasing the complexity of fisheries management. The sustainable development of Fisheries needs to develop a comprehensive management system that can meet all kinds of challenges. This paper proposes several areas of effort that can actively respond to the complex challenges of fisheries.
\end{abstract}

Keywords: CCS concepts, Social and professional topics, Professional topics, Computing and business, Economic impact, Fisheries, Governance, Australian Eastern Tuna and Billfish.

\section{INTRODUCTION}

The Eastern Tuna and Billfish Fishery (shaded area in Figure 1) comprises the Exclusive Economic Zone extending from Cape York to the Victoria-South Australia border, including sea area around Tasmania ("Figure 1"). It is one of the

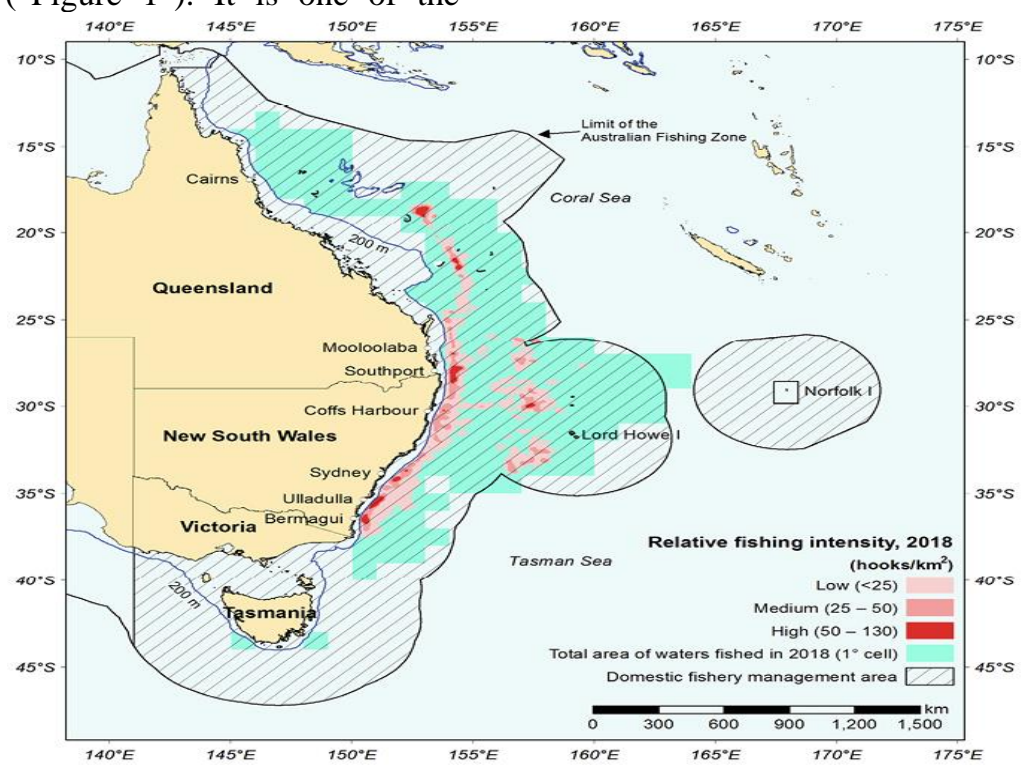

Figure 1 Relative fishing intensity in the Eastern Tuna and Billfish Fishery [3]. 
The total capture production of yellowfin tuna in ETBE from 2016 to 2017 was 4624 tons, accounting for only $0.316 \%$ of the global capture production of that year (1462540 tons). Both tuna and billfish play a unique role in Australian society, especially in coastal communities.

People still need a self-sufficient fishing industry to obtain efficient and high-quality protein [1], while at the same time reaping economic benefits from transactions conducted almost globally. Maintaining a sustainable marine fishery system can not only provide more industry-related jobs and contribute to the livelihood of its practitioners [2], but also maintain the stability and diversity of the complex ecosystem in the eastern waters of Australia. Therefore, it is of social and ecological significance to study the potential challenges of ETBF both at present and in the future.

\section{EAST AUSTRALIAN CURRENT SHIFTING}

The impact of climate driven change on marine fishery productivity has become a hot topic. The high sensitivity of marine species to climate driven change has become more and more obvious. The East Australian Current (EAC) plays a key role in the marine ecosystem in the southeast of Australia. As the western boundary current of the subtropical Pacific and the largest ocean current near the Australian coast, it transports a large amount of warm water and nutrients from the tropical region along the east coast to the south, as well as the marine biota and its survival debris ("Figure 2").

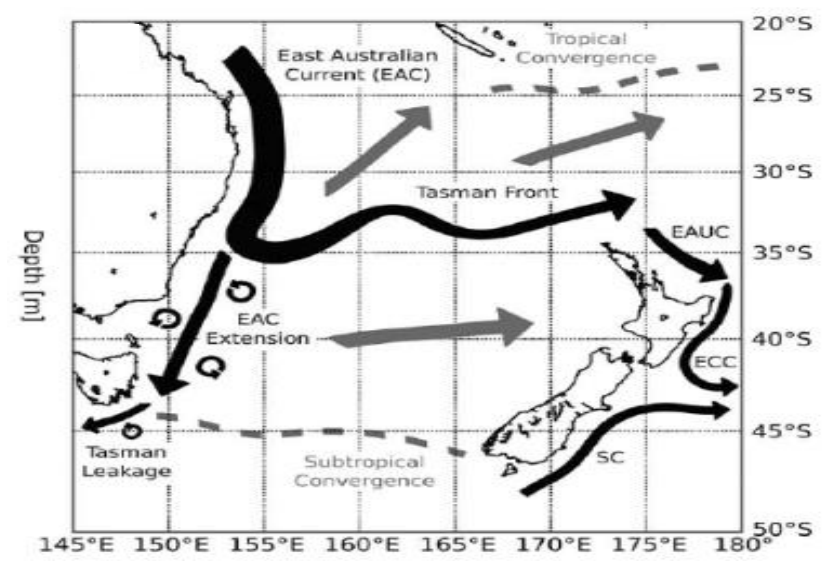

Figure 2 Map shows the EAC area and its general currents. Schematic of the regional oceanography including ocean currents and fronts. [4]

Over the past few decades, many observations and studies have shown that the southward penetration of the EAC has increased, resulting in warmer and saltier waters on the east coast of Tasmania (averaging $2.28^{\circ} \mathrm{C} /$ century and 0.34 PSU / century, respectively) during the period 1944-2002 [5]. As more warm core eddies appear in the southern waters, some pelagic species such as Striped marlin and Albacore will also be expected to move southward to the north east of Tasmania. At present, the main capture areas of ETBF are concentrated between $25^{\circ} \mathrm{s}$ and $30^{\circ} \mathrm{s}$ [6]. However, it is expected that by the end of this century, the location of fishery resource abundance will change significantly, and the key species in ETBF are expected to decrease in tropical areas and move to the polar regions. In this case, the first problem will be the division of jurisdiction. The demarcation of federal fisheries may need to be changed, followed by the secondary impacts on fleet and infrastructure deployment, fishermen migration, and tradable quota shares regulations [7].

The southward migration of warm waters can also cause changes in the concentration of potential prey and predators (or competitors), but the net effects of this change to fishery production are uncertain. On the one hand, many studies have observed the southward expansion of phytoplankton community [8], which will provide more low-level nutrients for the ecosystem of the water area and promote the enhancement of fishery abundance. On the other hand, more predators (or competitors) such as sharks in the southern waters due to the warming of water temperature will increase the predation risk (or predation pressure) of tuna and flounder, which will have a negative impact on fishery abundance.[9] More observational data and research are needed to 
discuss the exact net impact of climate-driven changes in prey and predator (or competitor) concentrations on catch.

\section{HIGH LABOR COST}

An important challenge for commercial fisheries is to maximize fishery revenue, which means not only increasing the catch, but also reducing the cost per fish. However, the long-term high labor costs make Australian Fisheries inferior to some other countries such as Korean and France. Unit labor costs in Australia have continued to rise significantly over the past decade, which means paying more for labor per unit of output ("Figure $3 ")$. The costs are defined by persons employed and take the unit labor costs of 2010 as 100.

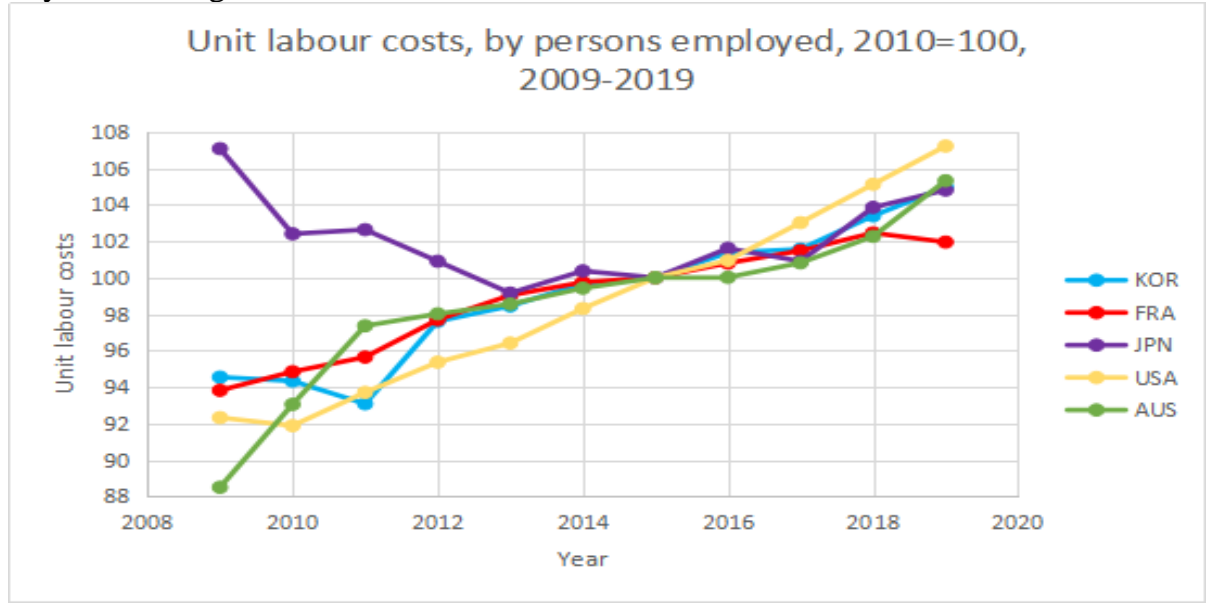

Figure 3 Unit labor costs of five different countries during 2009 to 2019.

Although according to Australian Bureau of Agricultural and Resource Economics and Science' report,[10] the increase of fishing income exceeds the increase of fishing cost, the high labor cost still brings great pressure to the competition of fishery trade and production. Hence, it is difficult to achieve or maintain the maximum net income of fishery. At the same time, limited by fishery regulatory policies (such as Total allowable commercial catch Determination), the catch of tuna and billfish, the number of vessels that can be fished and the fishing methods that can be used are strictly managed. Therefore, the profit that fishery companies can expand by increasing catch is limited.

Under the pressure of high labor cost, they may withdraw from fishery to switch to other industries with relatively higher income, or transfer to areas with lower labor cost and open to foreign vessels for fishing, and even exploit fishery workers -- a phenomenon that is often ignored but actually exists. In recent years, the scandals about the slave labor in Thailand's marine fishery have attracted worldwide attention (e.g. [11]; [12]). The fishery management system of New Zealand, which is regarded as the world's leading level, is also considered to have the problem of forced labor [13]. In Australia, commercial fishing is also regarded as heavy work and lack of social and selfidentity. According to Dominion Consulting's report (2004) [14], 69\% of fishermen had not completed formal schooling to Year 12. Moreover, with an average age of 54, New South Wales trawler fishermen have about 70 hours of normal working week during the fishing season, compared with the general level of around 37.5 hours [15]. Many young people no longer want to work in commercial fishing. Therefore, with the aging of the last generation of commercial fishermen and the development of other emerging industries, the fishery labor force is more and more insufficient, which promotes the rise of labor cost. In turn, the high labor cost has exacerbated the decline of the traditional fishing industry, and the loss of labor will become more obvious.

\section{GLOBAL SEAFOOD TRADE AFFECTION}

Australian tuna exports have increased significantly since 1989 and peaked between 2000 and 2003 ("Figure 4"). Due to the impact of the decline in fishing and other reasons, tuna exports have declined, but Australia still plays an important role in the global seafood trade. Tuna trade covers almost the whole world, among which the United 


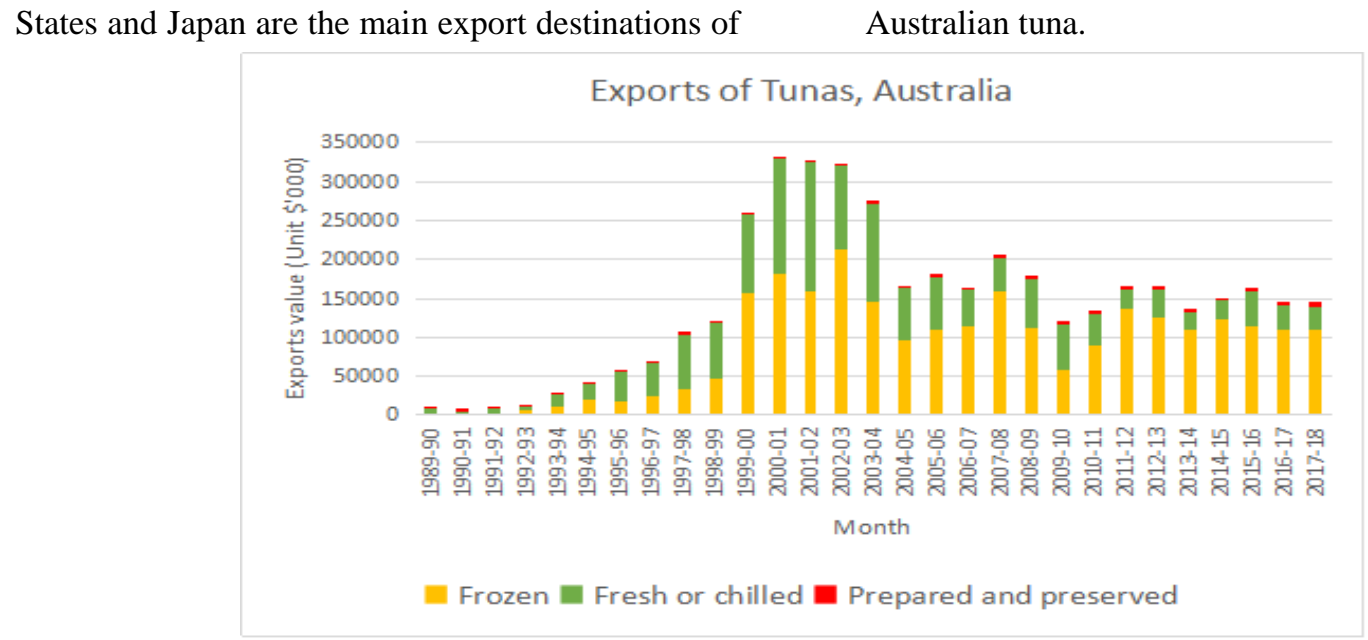

Figure 4 Yearly exports of tunas of Australia from 1989 to 2018.

With the globalization of seafood trade, Australian Fisheries have expanded more development markets. For example, from 2017 to 2018, due to the continued strong import demand from the United States, the average price of bigeye tuna rose by $6 \%$ to about $\$ 11.5$ per kilogram [16]. But at the same time, the unpredictable international market has also brought more challenges to Australian Fisheries. Australia's global seafood trade is largely affected by the fluctuation of exchange rate. At the same time, due to the differences in tax, income remittance, regulatory policies and even ethical traditions of each trade destination, the global seafood trade will bring complex and sustained impact on Australian Fisheries. Since the 21 st century, more countries or regions have joined the tide of Global trade. Affected by inflation, labor costs, national income and government policies, Australia's competitive advantage in the international trade market has declined. Taking 1970 as a reference, the trade terms of Australia in the past decade are less favourable than that in 1970 , that is, the exchange efficiency becomes worse than that of 1970 ("Figure 5").

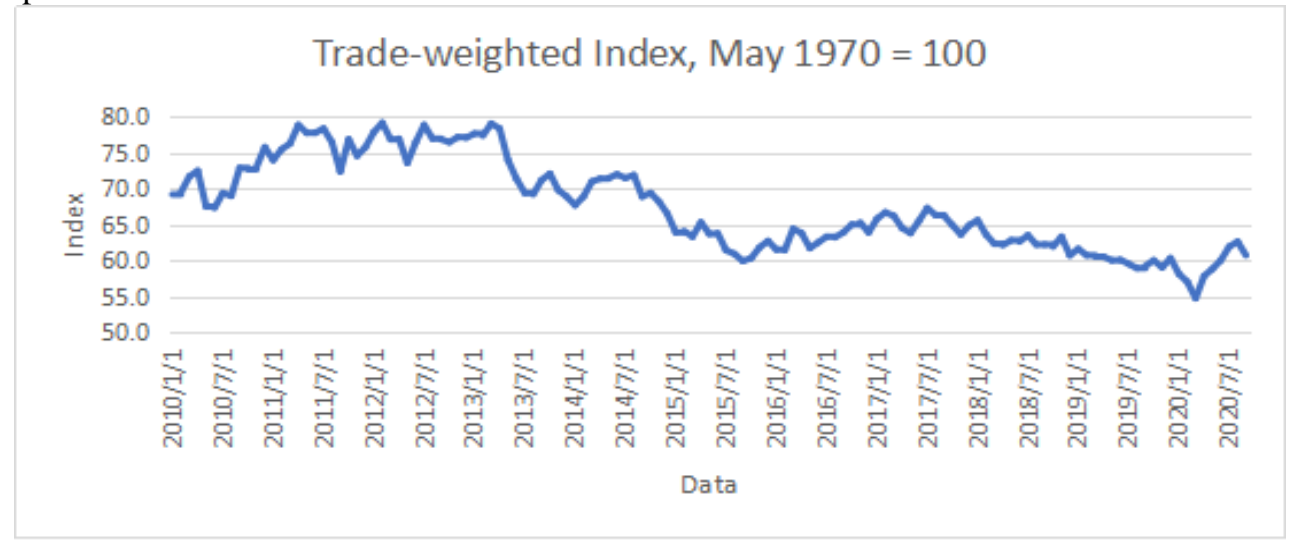

Figure 5 Monthly trade-weighted index taken from January 2010 to latest complete month of current year. 


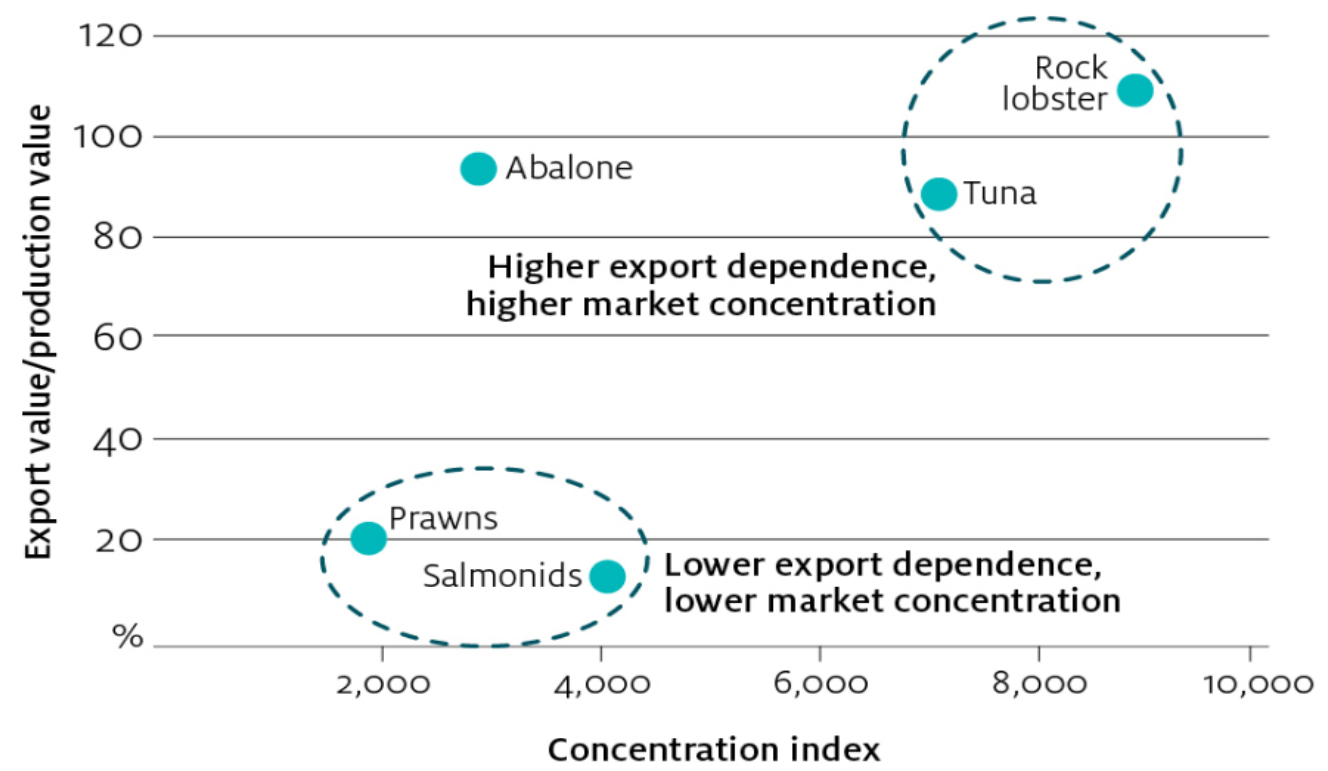

Figure 6 Export market concentration of major fisheries products, 2018-19 [17].

Australia's tuna industry is mainly exportoriented. Compared with the past, Australia's tuna export dependence has become higher, and the market concentration has also become higher ("Figure 6"). As the world's largest consumer of sashimi grade tuna, Japan accounted for about $78 \%$ of the total tuna exports of that year in 2017-2018. In the past decade, due to the change of Japanese consumer demand and the diversification of tuna trade market [18], Japan's demand for Australian tuna has declined. In addition, the Japanese yen's slight depreciation against the AUD dollar ("Figure 7") has also put downward pressure on the value of tuna exports to Japan ("Figure 8"). The outbreak of coronavirus (COVID-19) in 2019 may aggravate the competitive pressure on Australian tuna trade. Although the final impact depends on the extent and duration of the outbreak and the effectiveness of control measures [19], the price of tuna will be under downward pressure in view of the reduced demand and the limited alternative market for some commodities.

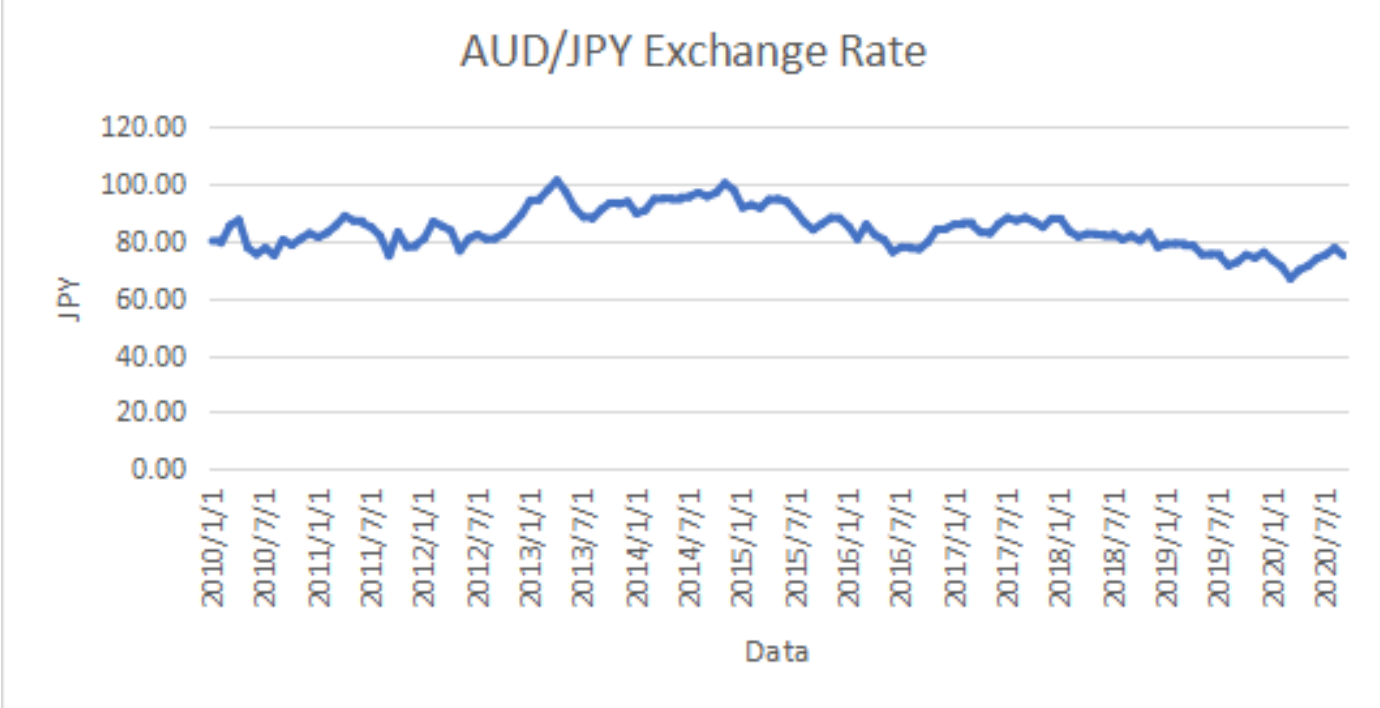

Figure 7 Exchange rate change of Australian dollar against Japanese Yen. 


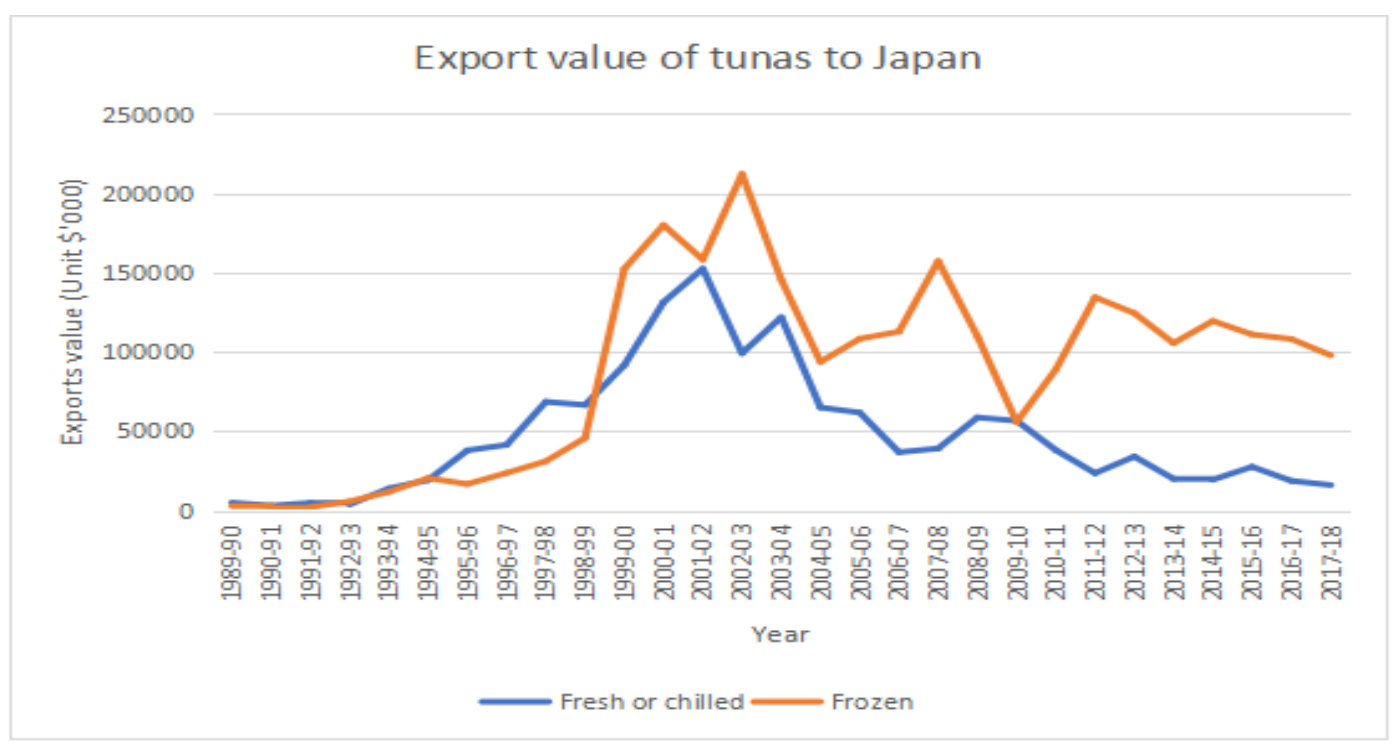

Figure 8 Export value of tunas to Japan.

\section{RECREATIONAL FISHERY}

As a traditional recreational activity in Australia [20], recreational fishing has become more and more popular. The proportion of recreational fishery in the total national fishery receipts is increasing day by day, but the influence of recreational fishery is often ignored [21]. Different from the management strategy of pursuing high net profit in commercial fishery, the purpose of leisure fishermen is to enjoy the pleasure, and its development makes modern fishery more complicated. The attention of the society and the government is more focused on the management of the commercial fishery, therefore the leisure fishery is relatively lack of supervision. However, the impact of recreational fishing on the ecological environment, such as the large amount of cumulative fishing and the pollution caused by fishermen is also obvious. At the same time, Australia's leisure fishery information is scarce and difficult to obtain. Moreover, some government protection measures, such as expanding the fishing ban area of the Great Barrier Reef Marine Reserve have also been opposed by leisure fishery groups [22]. How to set up sustainable management strategies to balance commercial and recreational fisheries and maximize the use of fisheries to bring benefits to the public will become a great challenge for Australian Fisheries.

\section{DISCUSSION}

It is seen that ETBF is facing threats from various sources, and governance must comprehensively consider these complex changes, which puts forward higher requirements for the flexibility of the institutional approach. The single and strict management system needs to be reexamined, and the ability of independent adjustment needs to be given to the fishery to adapt to different risk changes. The promotion of the existing individual transferable quota (ITQ) management system can increase the adaptability of ETBF in the face of various changes, such as the spatial displacement of fish stocks, and set total allowable commercial catch is also conducive to prevent overfishing and ecological damage. However, the existing management system still needs to consider more interdisciplinary impacts on the basis of ecological protection. For example, there is a dispute that TACC is higher than the level of maximizing economic output [23], and the main reason for the dispute is the lack of formal Bioeconomic analysis. The goal of Fisheries governance is to maximize the benefits, but only focusing on a single area may reduce the effectiveness of governance methods. Sustainable development of positive fisheries needs to be coordinated and balanced in ecological, economic, legal, and other fields. Therefore, the cultivation of interdisciplinary researchers and the establishment of multi-disciplinary research institutions should be promoted in the future to face complex challenges. Fishery governance needs a more comprehensive multidisciplinary thinking to re-examine the old 
problems and solve the new problems. At the same time, it is also important to provide alternatives for fishermen (such as other fishing grounds or other employment opportunities) and to re-manage the resources between commercial and recreational fisheries.

\section{CONCLUSION}

This paper has been focused on the ETBF and discussed some of the challenges it is facing now and could potentially face in the future. The climate driven change is a huge challenge for ETBF both at present and in the future as the EAC transport a large amount of properties from north to south within this region, such as warm waters and nutrients, which are critical for fishery species. The EAC Extension tends to strengthen which means warm waters are transported to the south and warmer waters can be found further south. This could change the location of fishery resource abundance and thus influence the fishery productivity.

It is suggested that more research should be done to relate the effects of EAC with fishery with aims to mitigate this climate driven effect. Another challenges that ETBF has faced is the high labor cost in Australia. It has very quick rise in unit labor cost over the last decade when comparing with some other countries, which decreases the net income of fishery. In addition, the fishery regulatory policies limit the profit of fishery companies, which could bring other consequences such as withdrawal of companies, forced labors, etc. There is also a challenge from the global seafood trade. This is a very complex system that involves countries globally and depends on a lot of factors such as exchange rate, demand from the trade destination countries, etc. Last but not the least, recreational fishery also brings challenge to ETBF and it may be the largest unknow factors due to lack of supervision and information. However, its effects are significant and cannot be ignored. Therefore, some strategies should be developed to better monitor and manage the recreational fisheries and to balance with commercial fisheries.

\section{AUTHORS' CONTRIBUTIONS}

This paper is independently completed by Xinyue Zhao.

\section{REFERENCES}

[1] Bell, J. D., Kronen, M., Vunisea, A., Nash, W. J., Keeble, G., Demmke, A., Potifex, S., \& Andréfouët, S. (2009). Planning the use of fish for food security in the Pacific. Marine Policy, 33(1), 64-76.

[2] Ferrol-Schulte, D., Wolff, M., Ferse, S., \& Glaser, M. (2013). Sustainable Livelihoods Approach in tropical coastal and marine social-ecological systems: A review. Marine policy, 42, 253-258.

[3] Larcombe, J., Patterson, H., \& Mobsby, D. (2020). Chaper 21: Eastern Tuna and Billfish Fishery. In Department of Agriculture, Water and Environment (ABARES), Fishery status reports 2020, 377-399.

[4] Oliver, E. C. J., \& Holbrook, N. J. (2014). Extending our understanding of South Pacific gyre "spin - up": Modeling the East Australian Current in a future climate. Journal of Geophysical Research: Oceans, 119(5), 2788-2805.

[5] Ridgway, K. R. (2007). Long - term trend and decadal variability of the southward penetration of the East Australian Current. Geophysical Research Letters, 34(13).

[6] Young, J. W., Hobday, A. J., Campbell, R. A., Kloser, R. J., Bonham, P. I., Clementson, L. A., \& Lansdell, M. J. (2011). The biological oceanography of the East Australian Current and surrounding waters in relation to tuna and billfish catches off eastern Australia. Deep Sea Research Part II: Topical Studies in Oceanography, 58(5), 720-733.

[7] McIlgorm, A., Hanna, S., Knapp, G., Le Floc'H, P., Millerd, F., \& Pan, M. (2010). How will climate change alter fishery governance? Insights from seven international case studies. Marine Policy, 34(1), 170-177.

[8] Thompson, P. A., Bonham, P., Waite, A. M., Clementson, L. A., Cherukuru, N., Hassler, C., \& Doblin, M. A. (2011). Contrasting oceanographic conditions and phytoplankton communities on the east and west coasts of Australia. Deep Sea Research Part II: Topical Studies in Oceanography, 58(5), 645-663.

[9] Last, P. R., White, W. T., Gledhill, D. C., Hobday, A. J., Brown, R., Edgar, G. J., \& 
Pecl, G. (2011). Long - term shifts in abundance and distribution of a temperate fish fauna: a response to climate change and fishing practices. Global Ecology and Biogeography, 20(1), 58-72.

[10] Patterson, H., Woodhams, J., \& Curtotti, R. (2020). Chaper1: Overview. In Australian Bureau of Agricultural and Resource Economics and Sciences (ABARES), Fishery status reports 2020, 1-31.

[11] Fujita, K., Endo, T., Okamoto, I., Nakanishi, Y., \& Yamada, M. (2010). Myanmar migrant laborers in Ranong, Thailand (No. 257). Institute of Developing Economies, Japan External Trade Organization (JETRO).

[12] Robertson, P., \& Van Esveld, B. (2010). From the Tiger to the Crocodile: abuse of migrant workers in Thailand. Human Rights Watch.

[13] Simmons, G., \& Stringer, C. (2014). New Zealand' s fisheries management system: Forced labor an ignored or overlooked dimension? Marine Policy, 50, 74-80.

[14] Dominion Consulting (2004). An assessment of economic and social issues in the New South Wales Ocean Trawl Fishery Management Strategy. https://www.dpi.nsw.gov.au/_data/assets/pdf _file/0010/632269/Ab-EIS-Dominionreport.pdf

[15] McPhee, D. P. (2008). Fisheries management in Australia. Federation Press.

[16] Steven, A.H., Mobsby, D., \& Curtotti, R. (2020). Australian fisheries and aquaculture statistics 2018, Fisheries Research and Development Corporation project, ABARES, Canberra.

[17] Mobsby, D., Steven, H. A., \& Curtotti, R. (2020). Australian Fisheries and Aquaculture Outlook 2020. ABARES, Canberra, Australia, 9.

[18] Campling, L, Antony, L \& McCoy, M 2017, The Tuna Longline Industry in the Western and Central Pacific Ocean and its Market Dynamics, Pacific Islands Forum Fisheries Agency, Honiara.

[19] Mobsby, D., Steven, H. A., \& Curtotti, R. (2020). Australian Fisheries and Aquaculture Outlook 2020. Department of Agriculture,
Water and Environment (ABARES), Canberra, Australia, 9.

[20] Henry, G. W., \& Lyle, J. M. (2003). National recreational and indigenous fishing survey.

[21] McPhee, D. P., Leadbitter, D., \& Skilleter, G. A. (2002). Swallowing the bait: is recreational fishing in Australia ecologically sustainable? Pacific conservation biology, 8(1), 40-51.

[22] Prayaga, P., Rolfe, J., \& Stoeckl, N. (2010). The value of recreational fishing in the Great Barrier Reef, Australia: A pooled revealed preference and contingent behaviour model. Marine Policy, 34(2), 244-251.

[23] Gardner, C., Hartmann, K., Punt, A. E., \& Jennings, S. (2015). In pursuit of maximum economic yield in an ITQ managed lobster fishery. Fisheries Research, 161, 285-292. 